\title{
Workforce diversity policies in practice: drivers and barriers in local administrations
}

\section{Christine Lang}

To cite this article: Christine Lang (2020): Workforce diversity policies in practice: drivers and barriers in local administrations, Ethnic and Racial Studies, DOI: 10.1080/01419870.2020.1754444

To link to this article: https://doi.org/10.1080/01419870.2020.1754444

\section{(6) 2020 The Author(s). Published by Informa} UK Limited, trading as Taylor \& Francis Group

\section{0.}

Submit your article to this journal $\widetilde{ }$

Џ Article views: 219

Q View related articles $₫$

View Crossmark data $\asymp$

Citing articles: 1 View citing articles 


\title{
Workforce diversity policies in practice: drivers and barriers in local administrations
}

\author{
Christine Lang
}

Max Planck Institute for the Study of Religious and Ethnic Diversity, Göttingen, Germany

\begin{abstract}
Employment in the municipal workforce is a key area in which cities shape the inclusion of their population of immigrant origin. While many European cities have developed policies aiming to foster the employment of staff of immigrant origin, little is known about the drivers and barriers of their implementation. Based on a comparative case study of local administrations in one German regional state and drawing on organizational theory, this article explores the role of organizational factors. It shows how the interplay of mainly two factors matters: support from the administrative leadership and the pragmatic recruitment rationalities of the human resources practitioners. Additionally, the findings suggest that the local identity as municipality more or less shaped by immigration also informs practices. The article argues that to understand the implementation of policies promoting workforce diversity organizational structures and rationalities must be considered.
\end{abstract}

ARTICLE HISTORY Received 10 July 2019; Accepted 6 April 2020

KEYWORDS Diversity policies; public administration; organizations; local; employment; staff of immigrant origin

\section{Introduction}

Employment in municipal administrations is a field where cities can significantly shape the inclusion and participation of their population of immigrant origin. Since municipal authorities are important local employers, access to the civil service is a crucial dimension of economic inclusion. Moreover, it implies participation in the implementation of policies that affect the life chances of residents, and it conveys a symbolic meaning. While a fairly representative civil service suggests openness and equal opportunities (Mosher 1982), an obvious underrepresentation of immigrant or minority residents may signal unequal chances and limited belonging. Municipal authorities 
importantly influence employment and career opportunities by way of the recruitment and selection procedures applied and by possibly adopting measures to foster the recruitment of underrepresented groups. Across Europe, cities have introduced policies to promote equal opportunities and diversity within municipal workforces, though in different forms and to different degrees (Spencer 2008). While in the UK and the Netherlands, respective policies date back to the 1980s and 1990s (Solomos 1989; Groeneveld and Verbeek 2012), they were introduced more recently in countries without a multicultural tradition such as Germany and France (MezianiRemichi and Maussen 2017).

In Germany, cities began to develop policies aiming to promote the employment of people with a "migration background"1 in the mid-2000s. At this time, many German cities reformulated their integration policies (Gesemann and Roth 2009) in the course of a reorientation of the national approach to immigration and integration (Schönwälder and Triadafilopoulos 2016). In the 2010s, the national government also adopted the aim to increase the share of employees with a migration background in public administration (Die Bundesregierung 2012). However, while we witness a wide diffusion of the policy objective, major differences exist between cities regarding the introduction of measures (Gesemann, Roth, and Aumüller 2012, 54). Further, we know little about their actual implementation. This reflects a more general scarcity of research on responses to diversity in public organizations (Bührmann and Schönwälder 2017), despite the growing body of research on local integration and diversity policies (e.g. Alexander 2007; Dekker et al. 2015; Martínez-Ariño et al. 2019).

This article examines the implementation of policies promoting employment of staff with a migration background in selected local administrations in Germany. By choosing cases located within the city-state of Berlin, I can compare the practices in different local administrations situated within the same political and institutional context. Among German states, Berlin is one case that has introduced policies to increase the share of employees with a migration background and did so relatively early. Policies focus on access of young people to vocational training, the key route into the middle grade of the civil service, where internal career opportunities allow access to the middle management. Yet, implementation differs strongly between the administrations of the districts (Bezirke), the local level in the city-state. While in some districts, hiring routines have continued practically unaltered and numbers of new staff members of immigrant origin remain low, others seem to have effectively implemented measures to foster their recruitment. What factors further or prevent the implementation of policies promoting the employment of immigrants and their descendants in local administrations?

Drawing on in-depth qualitative case studies and theoretical approaches from organizational sociology, I will argue that the interplay of mainly two 
factors matters: first, how the administrative leadership supports policies for a more diverse workforce but also general innovation of human resources strategies, second, whether targeting individuals of immigrant origin corresponds to the recruitment rationalities of the human resources practitioners. Further, the analysis indicates that a local identity as a district more or less shaped by immigration also informs practices. The article argues that to understand the implementation of workforce diversity policies, ${ }^{2}$ we must consider the organizational structures and rationalities underlying recruitment-related decisions and administrative practices more generally.

In the following, I will first draw on literature from organizational research to develop hypotheses regarding the implementation of policies to increase workforce diversity. In the second section, I will introduce the empirical case and the data before turning to the presentation of the case studies in the next three sections. The final section summarizes and discusses the findings.

\section{An organizational perspective on workforce diversity policies in practice}

Research on equal opportunity and diversity policies in municipal authorities and other public organizations has regularly documented "implementation gaps" and the persistence of inequalities in minority members' access to positions (e.g. Young 1987; Liff and Dale 1994; Creegan et al. 2003; Naff and Edward Kellough 2003; Groeneveld and Verbeek 2012). A number of studies have further investigated the factors fostering diversity policy adoption in public and private sector organizations. While there is contradictory evidence regarding the relevance of external normative pressure (Pitts et al. 2010; Dobbin, Kim, and Kalev 2011), these studies indicate several internal factors that are beneficial to diversity policy implementation. They include the presence of women or minorities in leadership positions (Dobbin, Kim, and Kalev 2011; Cook and Glass 2015), structures allocating responsibility for change such as diversity plans or representatives (Kalev, Dobbin, and Kelly 2006), human resources professionals (Edelman 1992), and corporate culture (Dobbin, Kim, and Kalev 2011). However, while emphasizing the importance of internal factors, these mainly large-scale quantitative studies cannot explain how and why the factors assumed to matter operate in practice. Further research is thus required (Dobbin, Kim, and Kalev 2011, 405; Groeneveld and Verbeek 2012, 370).

This article focuses on the processes and practices within local administrations to advance our understanding of the ways in which internal organizational factors shape the implementation of workforce diversity policies. I suggest drawing on organizational sociology and combining two kinds of literature: neo-institutionalist approaches focussing on the link between 
organizations and their institutional environment and the systems theory approach emphasizing the internal characteristics of organizations.

Neo-institutionalist approaches in organizational sociology argue that organizations typically respond to institutional expectations - such as policy objectives to improve workforce diversity - by "decoupling" symbolic adjustments of the features displayed to the environment from actual practices (Meyer and Rowan 1977), for instance in separating "talk" from "action" (Brunsson 2006). Decoupling allows to balance the possibly contradictory requirements for organizational survival: securing legitimacy - understood as crucial imperative for organizations (Deephouse and Suchman 2008) - by demonstrating compliance with societal rules, expectations and beliefs while at the same time efficiently solving the internal practical problems (Meyer and Rowan 1977, 357). Decoupling particularly responds to inconsistent institutional environments, which organizations often face (Brunsson 2006, 8-9; Boxenbaum and Jonsson 2008, 86). Organizations that are primarily shaped by their institutional environment and rely on societal acceptance for survival, including public administrations, are described as particularly likely to employ strategies of decoupling (Scott and John 1991, 125; Brunsson 2006, 14). However, the literature also emphasizes that by expecting decoupling, we should not ignore that even symbolic adjustments might in the longterm entail changes of actual practices (Edelman 1992; Bromley and Powell 2012, 485).

While neo-institutional approaches focus on the relationship between organizations and their environments, the systems theory approach (Luhmann 2000; Nassehi 2005) draws attention to internal rationalities and structures shaping practices. It allows conceptualizing why organizations may respond differently to a similar environment. Adopting a radical constructivist perspective, the approach states that the organizational environment is no objective given or "independent reality" (Luhmann 2003, 33) but a product of the organizational structures and modes of observation. Accordingly, organizations do not adapt to given institutional contexts, but to the contexts that they construct or "imagine" internally (Luhmann 2000, 78). This shifts the focus to the organizational structures and their differences between organizations. The structures shape whether environmental irritations are perceived as relevant information requiring action, what kind of problems they raise and what kind of solutions are considered and put into practice. Three types of organizational structures, or "decision premises", are distinguished, which have both formal and informal dimensions (Luhmann 2000; Kühl 2013). ${ }^{3}$ These are programmes defining the conditions and purposes for decisionmaking; communication channels, i.e. the organization of positions and responsibilities, which defines who takes what kind of decisions; and the personnel, i.e. staff members with their characteristics, which also structure the organizational communication. ${ }^{4}$ Further relevant characteristics are the 
organizational culture - the institutionalized values, knowledge and habits that often unconsciously shape practices (Luhmann 2000, 240-249) - and the organizational identities, which might latently inform practices (Seidl $2003,136)$. In the case of local administrations, the organizational identities can include features of the territory administered, i.e. the city or district (Lang 2019).

Combining these approaches to study the implementation of workforce diversity policies in local administrations, we may thus expect that decoupling and merely symbolic adjustments occur, but also that practices differ between administrations depending on their specific - and possibly differing - structures, cultures and identities. Before investigating the practices in three local administrations in Berlin, the following section will present the empirical case and data.

\section{Empirical case and data}

The analysis draws on empirical data gathered from 2012 to 2015 in the German state of Berlin. Berlin was among the first German states that introduced policies to foster the employment of staff with a migration background. It was chosen because the administrative context of the city-state - where the city of Berlin represents the regional state level and the districts the local level - allowed comparing responses to these policies in different local administrations situated in the same political, institutional and discursive context. This helps identify organizational factors shaping whether and how these policies are put into practice.

In 2005, the objective "to increase the share of employees with a migration background" in public administrations was added to the state's integration policies (Der Beauftragte des Senats von Berlin 2005). The underrepresentation of the immigrant population in the civil service had been subject of political debates since the 1990s, but it only entered the official political agenda following a change in the city-state government - from a conservative-led grand coalition to a coalition of Social Democrats and socialist Left - and the reorientation of national integration policies in the early 2000s. Policies primarily aimed to foster the labour market integration of a disadvantaged group, especially young people of immigrant origin, and to promote the "intercultural opening" of public administrations in order to improve service provision for the immigrant population. Promoting equal opportunities was secondary. This objective did not become more prominent before the 2010 s and continues to be challenged by a strong discourse arguing that the principle of formal equal treatment already guaranteed equal opportunities.

The new policies mainly focussed on vocational training (Ausbildung), in Germany a highly institutionalized and recognized pathway into a large range of qualified occupations. The three-year training combines a traineeship 
in the employing organization with theory at vocational schools. Employment in the middle grade of the civil service (e.g. as administrative clerk) is conditional on completion of the specific vocational training; higher grades require university studies. Usually, trainees are offered continued employment after successful completion of the training. Internal careers can lead up to the middle management. The recruitment of trainees thus has long-term effects on the staff composition. During the time of my fieldwork, state and district administrations recruited between 500 and 700 new trainees every year. It was the main form of regular recruitment during a time of staff cuts from the late 1990s to the early 2010s.

Measures introduced by the state to foster the recruitment of staff with a migration background mainly included a campaign called "Berlin braucht Dich!" ("Berlin needs you!") launched in 2006 to promote vocational training in the civil service among young people of immigrant origin. It has evolved into a comprehensive programme that supports internship offers, provides promotion material and facilitates contacts between schools and employers. In 2007, the share of new staff members with a migration background was included in the state's "integration monitoring" as one indicator for the "intercultural opening" of public administrations (Der Beauftragte des Senats von Berlin 2007). The "Law on Participation and Integration", adopted by the city-state in 2010, provided a legal frame and announced targets, benchmarking and regular reporting (Abgeordnetenhaus von Berlin 2010). However, the announced target was politically contested for allegedly violating the principle of equal treatment. Moreover, in the administrative structure of the city-state the law cannot exert coercive but only "softer" normative pressure on the district authorities. The 12 districts of Berlin enjoy relative autonomy in the implementation of integration policies and in matters of staff recruitment. Official employee statistics in German public administrations do not record a "migration background". 5 But the migration background of newly-hired trainees has been registered each year since 2006, and differences between districts are noticeable. When fieldwork was conducted in 2012-15, few districts had regularly shown shares of new trainees with a migration background between 25 and 50 per cent since 2006, whereas the numbers in others had varied largely between the years, and some districts had rarely reported more than 10 per cent of trainees with a migration background (BQN 2014).

To study factors shaping the implementation of the described policies in local administrations, the article draws on qualitative material. The research concentrated on the recruitment of trainees for administrative professions as the policies' main focus. This also guaranteed comparability across administrations. The empirical material encompasses 60 semi-structured interviews with different actors involved in politics and practice of recruiting employees with a migration background on the district and city-state levels: HR officers, integration commissioners, heads of administrative departments, representatives 
from political parties and NGOs as well as trainees and employees of immigrant origin. Further, it comprises participant observation in the recruitment process (e.g. in the selection of applications, in interviews, and at job fairs), and analysis of political, administrative and media documents. The data were analysed based on grounded theory (Strauss and Corbin 1996), supported by the software MAXQDA. Categories included, among others, the recruitment practices and underlying logics of action, the problem perceptions, migration-related differentiations, organizational structures as well as features of the institutional and local environments (for more details see Lang 2019).

For the in-depth study, I selected three district administrations. Case selection was based on documents, first interviews and data on trainees with a migration background. The aim was to include most different cases regarding the responses to the city-state's policies and their effects on recruitment practices, in line with Mill's "method of difference" (George and Bennett 2005, 153). In administration $A$, the policies did not seem to have affected recruitment practices, and numbers of newly-hired trainees with a migration background had usually remained below 10 per cent. In administration B, a local target had been set, paralleled by rising numbers of trainees with a migration background, but the target was practically abandoned after few years and numbers dropped again. In administration $C$, several measures had been introduced to increase the share of trainees with a migration background and numbers had regularly figured around 25-35 per cent. All three cases had in common that the mayors were members of one of the governing parties in the city-state during their mandate (Social Democrats or socialist Left). Further, none of the personnel in leadership positions had a migration background. Therefore, neither political affiliations nor internal advocacy from minority members in managing positions (see Cook and Glass 2015) could explain differences.

The following analysis of factors affecting the implementation of policies to foster employment of staff of immigrant origin draws on the reconstruction of processes and practices in these three local administrations as they developed in the context of the policies introduced by the city-state.

\section{Administration A: continuity of established routines}

District $A$ is situated in the former Western part of Berlin. It figures among the districts with the highest shares of inhabitants with a migration background (ca. 36 per cent in 2014 when fieldwork was conducted) with the largest immigrant groups stemming from Turkey, former Yugoslavia, the former Soviet Union and Poland. In terms of social composition, the district has middleclass and wealthy neighbourhoods as well as poorer neighbourhoods. When I started my fieldwork in the district administration, the recruitment routines seemed unaffected by the political objective to increase the share of employees with a migration background despite low numbers. 
Yet, first initiatives to foster the recruitment of immigrant-origin staff date back to the mid-1990s. The longstanding foreigners' commissioner of the district (later relabelled "integration commissioner") had introduced the issue in the administration and cooperated with the vocational training unit, where she regularly asked whether trainees of immigrant origin had been recruited. Further, she advertised the vocational training opportunities in foreignlanguage newspapers. In the mid-2000s, when the objective to increase the share of employees with a migration background had become part of Berlin's integration policies, the commissioner initiated internal workshops and working groups to promote the intercultural opening of the administration. A mission statement on "intercultural opening" was developed. However, the commissioner's suggestion to include a target for the recruitment of staff with a migration background was rejected by the administrative officers involved. At the time of my research, the earlier measures and the mission statement seemed forgotten. As the head of the HR unit suggested:

This was probably an attempt to create an awareness in this house, and I would simply say that it failed because of the merciless power of the work overload of everyday life. (interview, November 2013) ${ }^{6}$

The implementation of measures to foster employment of staff with a migration background was hampered by different interplaying factors. This was, first, a lack of interest in intercultural opening policies on the part of the district mayor. He argued that promoting the employment of immigrant-origin staff was the responsibility of the city-state rather than the district and the state should improve the attractiveness of the civil service by ceasing to cut-down positions (protocol integration committee meeting, 24 October 2012). The new integration commissioner was less assertive and connected than her predecessor. She did not continue advertising in migrant media and enquiring at the vocational training unit about trainees with a migration background. Lacking support from the mayor, the commissioner had a hard time trying to implement initiatives to promote awareness for intercultural opening. Several attempts to organize workshops for executive staff members failed. Frustrated, she refrained from further efforts (interview, November 2013).

Further, unlike most of Berlin's districts, the district did not have a formal integration or intercultural opening policy. The district's parliament, which controls the administration and can initiate administrative action, had not passed a resolution instructing the administration to develop or implement respective measures. For the chair of the parliament's integration committee, who strove to strengthen this policy field, this was in part due to the prevailing district identity:

The district is relatively well saturated and bourgeois, and perceives itself as such, and that we now have $60-70 \%$ children with a migration background in 
primary schools, [...] that is not yet there in people's minds! (interview, May 2013)

Her proposal to organize a local integration conference focussing on the intercultural opening of the administrative workforce was rejected in the local parliament. Representatives of the majority parliamentary groups (Social Democrats and conservatives) argued that the district administration lacked the resources for such a conference, an argument which supported the mayor's view that integration policies were above all a matter of the citystate and not the district (protocol integration committee meeting, 27 August 2014). Intercultural opening had thus hardly become institutionalized in internal structures.

Moreover, the recruitment rationalities of the HR practitioners ran counter to measures to promote the employment of staff of immigrant origin. The recruitment procedure for the vocational training had not been changed for years and no-one challenged the established selection criteria (school grades and degrees, a written test on grammar, mathematics and general education plus an interview) as possibly creating structural disadvantages for candidates from outside the traditional target group. The trainee positions were not advertised, which was not conducive to fostering applications from young people from immigrant families, who often lack knowledge about employment opportunities in the civil service (Lang 2019). The above-mentioned state campaign "Berlin needs you!" aimed at reducing these barriers e.g. by supporting internships. The organization carrying out the project regularly asked all administrations for numbers of newly-hired trainees with a migration background. Like all public employers in Berlin, administration A officially participated in this campaign and delivered the requested numbers. However, this was "decoupled" (Meyer and Rowan 1977) from actual practices. The vocational training unit neither accepted interns, nor did it attend meetings of the campaign, and the (low) numbers of trainees with a migration background reported had no internal significance. As the head of the unit explained:

They show up every few months and ask if we have opportunities to take interns. They then get the information for the respective time. But I can't say that this is really a topic. We do not talk about it. It doesn't really matter at all (interview, May 2013)

The persistence of established routines was due, on the one hand, to a perceived contradiction between the political objective to recruit more staff members of immigrant origin and the organizational recruitment rationalities. The vocational training officers did not feel responsible for implementing what they perceived as integration measures for young people with difficulties on the labour market who possibly did not fulfil the expectations on trainees. As the head of the unit put it: 
In my view, there is a need, in any case, for the promotion of the persons concerned, but not regarding the question: Am I hiring them for the civil service, but regarding the question: How do I manage to motivate them to bring the required qualifications. (interview, May 2013)

This argumentation reflects the dominant framing of the policy as supporting the labour market integration of a disadvantaged group. On the other hand, the officers did not see a need to change their routines since, for them, they still fulfilled their purpose to hire enough qualified trainees. Although the number of applications for vocational training had considerably dropped over the years, they still deemed it sufficient. The decrease in applications is a trend across administrations, reflecting both demographic changes and changing educational preferences among high school graduates (Autorengruppe Bildungsberichterstattung 2014). In administration A, this was not perceived as imminent problem. Additional advertisement strategies were not considered.

Maintaining the established routines was further supported by the lack of a human resource strategy. The administration faced an important increase in vacancies due to an upcoming retirement wave affecting all administrations in Berlin. The human resources officers complained that the mayor, who was also the head of the personnel department, did not develop a plan on how to deal with this challenge. While the head of vocational training suggested increasing the number of trainee positions, the mayor decided to reduce them because of difficulties to place trainees with the different departments. In view of the planning uncertainties generated by missing or contradictory decisions from "above", developing new recruitment practices did not seem rational for the vocational training officers.

Summing up, several factors impeded the implementation of policies fostering workforce diversity and contributed to decoupling. Regarding the organizational structures (see Luhmann 2000), these were the non-existence of programmes on intercultural opening and future-oriented recruitment, and a lack of interest in these issues by the mayor as the personnel in the relevant decision-making position. Moreover, the HR officers' perceptions of recruitment needs and (lacking) benefits of addressing young people with a migration background contributed to maintaining established routines. Additionally, the local identity as district where immigration was not a prominent feature did not encourage action, a factor that turns out to be relevant in the comparison with the other cases.

\section{Administration B: temporary changes}

District $B$ is situated in the Eastern part of Berlin. Due to the different immigration history of the GDR, the share of population with a migration background is significantly lower than in district A (ca. 17 per cent in 2014). The largest 
immigrant groups here originate from former-Soviet-Union countries and Vietnam. In administration $B$, the introduction of policies to increase the share of staff members of immigrant origin entailed changes of practices; however, they were short-lived.

In the early 2000s, initiatives from the integration commissioner and the local immigrant advisory council were taken up by the district's mayor who installed a steering committee on intercultural opening, which involved the heads of different administrative departments. While, according to the former integration commissioner, this initially met with "enormous resistance" among the officers expected to participate, it proved productive and pushed the issue of the employment of staff with a migration background forward (interview, November 2013). The steering committee developed a local integration plan, which was adopted by the local parliament in 2006 and included a target for the recruitment of trainees with a migration background of 15 per cent, corresponding to the district's share of population with a migration background at the time. The vocational training unit was regularly asked to report on the progress. As different from administration $A$, the policy objective had thus become part of the organizational structures in form of a formal programme, a new "communication channel" - the steering committee - , and support by the relevant personnel, mainly the mayor.

This had an impact on recruitment practices. The vocational training unit actively tried to hire young people with a migration background to achieve the target. The officers established contacts to an association that offered courses for young women of immigrant origin preparing for vocational training in public administration and recruited several of the participants. Further, they sought to address the Vietnamese community, responding to the "political will" of the mayor, as the head of the unit reported (interview, May 2013), to specifically foster the employment of staff of Vietnamese origin. This was meant to help improve relations with the local Vietnamese public who allegedly felt uneasy in dealing with the administration. But the HR officers also ascribed positive cultural characteristics to the Vietnamese ("high performing", "comply with rules") that suited the general expectations on staff members. The training unit commissioned an expertise to find out how to increase the applications from young people of Vietnamese origin and presented the vocational training in Vietnamese associations. Moreover, to meet the target, the officers informally prioritized candidates with a migration background in hiring decisions. They invited candidates to interviews who had not passed the written test and gave bonus points for a "migration background" in the final ranking (interviews, May 2013, March 2014). This practice of "usable illegality" (Luhmann 1964, 304) allowed a short-term response to the political demands. The share of new trainees exceeded the target for several years. In contrast to administration A, the tight coupling of recruitment practices to the policy by the closely monitored target did not allow 
decoupling between symbolic adjustments and actual practice. However, while the expected numerical output was produced, this was decoupled from the regular recruitment routines, a form of decoupling that Bromley and Powell (2012) label "means-end decoupling".

The "migration boom" and "hype around the Vietnamese" as one officer described it (interview, March 2014) came to an end when the personnel in the decision-making positions changed. In 2011, a new mayor came into office who was not interested in intercultural opening. He initially planned to dissolve the steering committee and only maintained it after internal opposition, but the committee only met rarely. The head of the HR unit changed, too, and the successor pursued different foci. The target regarding trainees with a migration background continued to exist on paper but regular control had ceased. The structures established to promote recruitment were hollowed out, the tight coupling between policy and practice was loosened. At the time of my fieldwork, the target and the migration background of candidates hardly mattered anymore for the vocational training officers since the superiors did not ask for it. The numbers of new trainees with a migration background had dropped to one or two per year. Only few practices had remained. The officers still recorded the numbers of candidates and trainees with a migration background to be able to respond, "in case there's any interest in it again" (interview, March 2014), and the head of the unit pursued some promotion addressing the Vietnamese community, which she now described as based on personal motivation.

Further, the vocational training practitioners' recruitment rationalities contributed to abandoning attempts to hire more trainees of immigrant origin. Distinct from their counterparts in administration $A$, the officers perceived the need to develop new promotion strategies to counter the declining application numbers. But they also struggled with planning uncertainties and lacking support. The head of the HR unit, who considered the number of applications still sufficient, cut down resources for advertisement, which thwarted efforts for innovation. Furthermore, the promotion efforts did not target young people of immigrant origin anymore, since the former recruitment strategies enforced by the target had generated opposition from the vocational training officers. They complained that they had to hire candidates who did not meet the criteria just because of their "migration background" and that some of these candidates had not shown the expected performance. They now associated "migration background" with lacking suitability, generalizing negative experiences with few trainees into the now "justified" expectation that young people of immigrant origin would more likely cause problems. In their eyes, the political objective stood in fundamental conflict with their recruitment interests. The negative experiences had for them not only discredited the short-term hiring strategy as means to achieve the target but the policy itself. While the vocational training unit was initially 
rather active in the city-state's campaign "Berlin needs you!", the officers now openly shared their critique of the campaign's aim and had stopped attending meetings or offering internships. This withdrawal was further supported by the district's identity. The officers criticized that the campaign focussed on the "classic" immigrant districts in the Western part of Berlin and was not beneficial for their particular district context and immigrant groups, which they perceived to be less in need of integration measures. Like in administration A, participation in the campaign was now merely symbolic, decoupled from actual practices.

\section{Administration C: long-term changes in recruitment practices}

District $C$, situated in the Western part of Berlin, figures among the districts with the highest shares of inhabitants with a migration background, here combined with a large population of lower socio-economic status. Some of its neighbourhoods feature prominently in the public discourse on immigration-related problems. In administration $C$, the policy to increase the share of staff members of immigrant origin seemed successfully implemented. Since 2006 , the share of new trainees with a migration background had regularly figured around 25-35 per cent.

Factors contributing to this were first, concrete initiatives by the local mayor, fostered by the district's identity as shaped by immigration. In 2005-2006, when the political objective to increase the share of employees with a migration background was included in Berlin's integration policies, the mayor initiated a cooperation with a local association that offered preparation courses for young women of immigrant origin, the same project through which administration $B$ recruited trainees. The administration gave funding for the courses and reserved several trainee places each year for participants who successfully passed the recruitment procedure. Moreover, upon the mayor's initiative, the administration took an active role in the steering committee of the state's campaign "Berlin needs you!".

The mayor was the key actor in the district's integration policies and a visible figure in the German public debate on "integration problems" of the immigrant-origin population. His pivotal position was structurally anchored. In the district's parliament, an integration committee was only created when it became mandatory for all Berlin districts and it only had a consultative function. According to a long-standing member of the parliament, the parliament did not demand stronger institutionalization because the mayor "could not accept anyone beside him" (interview, June 2015). A formal programme for intercultural opening, like in administration $B$, did not exist. The mayor defended an explicitly "pragmatic" understanding of integration policy against "abstractly formulated concepts" (written response to a parliamentary interpellation, 5 May 2014). However, fostering the recruitment of staff with a 
migration background corresponded to the mayor's "pragmatic" approach, which was beneficial to the implementation of measures. The district's identity as one of Berlin's main immigrant districts further supported this. The long-standing head of the vocational training unit described how the decision to take a leading role in the "Berlin needs you!"-campaign had come about:

That was clearly a political decision. [...] We have a rather high quota of people here who at least have a migration background, or actually do not have a German passport, and the mayor is well known in Germany, so it was clear that of course this district must actively sit at the table. (interview, November 2013)

Undertaking visible action responded to public expectations, which focussed more on district $C$ as prominent immigrant district than on districts $A$ and B. These expectations required responses to not endanger the administration's legitimacy.

The top-down introduced measures entailed structural changes in recruitment practices - in contrast to administration B - because they increasingly overlapped with the recruitment rationalities of the vocational training officers. The specific recruitment channel of the preparation courses was abandoned in $\mathbf{2 0 1 0}$ for causing extra work and since not all trainees hired had fulfilled the expectations. However, the HR officers developed new recruitment strategies because they perceived a growing competition for qualified young people and thus the need to attract new target groups. This included, among others, young people of immigrant origin. In this district, in which an important share of school graduates now had a migration background, they were perceived as inevitable target group when the pool of potential trainees had to be increased. The new recruitment practices included a professionalized assessment procedure, active advertisement on job fairs and in local schools, and promotion material that aimed at presenting the administration as attractive and diversityfriendly employer. Considering young people of immigrant origin had become part of the regular recruitment practices. Different from administrations $A$ and $B$, the efforts to modernize recruitment received support and resources from the mayor (also head of the personnel department), who was interested in the vocational training scheme and in developing strategies to tackle the upcoming HR challenges.

In contrast to the previous two cases, the vocational training officers of administration C actively participated in the campaign "Berlin needs you!" because it served an important function for their promotion activities. The officers used the tools, material and networks provided and continued as an active member of the steering committee. They no longer understood the campaign as a specific integration policy measure, as it was introduced, but as a regular promotion measure. As the head of the training unit put it: 
Of course, with this I have promoted the town hall [...] as an employer brand. Because many people on the streets here don't even know about the vocational training here [...] and it's of course an advertising platform for us, to present ourselves as employers: 'Look, we have a great training, we have the opportunities after the training, look how great we are'. (interview, November 2013)

This re-interpretation as useful measure to tackle the perceived problems of staff recruitment is a major factor why in this case the measure was adopted. The focus on young people of immigrant origin became secondary; what mattered was the general visibility the administration could gain as employer.

Thus, the long-term changes of recruitment practices were the product of different interplaying factors. They include a mayor, who pursued active integration policies and supported future-oriented human resources strategies, and the recruitment rationalities of the HR officers, who strove to attract new target groups. Further, changes were supported by a local identity as "immigrant district". This fuelled public expectations, which required responses to secure legitimacy (Deephouse and Suchman 2008), and it informed the officers' perception that young people of immigrant origin were inevitable addressees of promotion activities.

\section{Conclusion}

This article set out to explore factors that affect the implementation of policies promoting the employment of staff of immigrant origin in local administrations. It focussed on internal organizational factors, which were investigated drawing on approaches from organizational sociology and reconstructing the practices in three local administrations in one German regional state (Berlin). The analysis shows how the interplay of different organizational structures and rationalities affects effective policy implementation. Particularly two factors proved to be relevant. First, support from the administrative leadership, mainly the mayors, played a crucial role. As the personnel in the relevant decision-making positions, they are part of the organizational "decision premises" (Luhmann 2000) structuring practices. Their interest and support were crucial for ensuring that measures were adopted and that further internal structures - formal programmes and communication channels (Luhmann 2000) - were developed and enforced. This not only included support for workforce diversity policies but also for the general innovation of human resource strategies. The analysis shows that if leadership support is lacking, formal structures may not be developed, and structures established to support the implementation of policies may be hollowed out. Second, the pragmatic recruitment rationalities at the operative level mattered. It was decisive whether the human resources practitioners perceived a need to change established routines to ensure recruitment of qualified employees 
in a changing labour market environment, and whether they perceived a benefit from attracting a new target group of immigrant origin. Where this was not (yet) the case, the new policies met with opposition and "decoupling" occurred (Meyer and Rowan 1977; Bromley and Powell 2012) between merely symbolic or short-term adjustments and the recruitment practices which continued unchanged. The political attempt to steer recruitment practices with a target for staff with a migration background even produced opposite effects and fuelled resistance against the policy. This echoes insights from the public administration literature indicating that targets as techniques to steer performance are likely to fail their objectives if they are not adequately designed (Hood 2006; Boswell 2018). Additionally, the comparison indicates that the local identity - as a district more or less shaped by immigration - may affect the adoption of measures. It becomes relevant as part of the organizational identity latently informing practices (Seidl 2003), and due to environmental expectations that may require action to secure legitimacy, a crucial imperative for organizations (Deephouse and Suchman 2008).

The findings contribute to the literature on drivers and barriers of diversity policy implementation by shedding light on the role of internal organizational structures and rationalities. They show that the implementation of diversity policies is contingent on organizational structures and on the administrative officers' perceptions of problems and requirements. This adds to previous studies arguing that it matters for effective implementation how policies are structurally anchored (Kalev, Dobbin, and Kelly 2006) by revealing how such structural characteristics operate in practice. Further, the findings suggest that we must consider the interplay of "top-down" and "bottomup" processes to understand the (non-)implementation of diversity policies. While formal policies and legal frameworks are important to initiate change, they may not be sufficient for substantive, long-term changes. The pragmatic rationalities underlying recruitment-related decisions, and administrative practice more generally, also play a crucial role. The implementation of practices furthering the employment of staff of immigrant origin requires that the officers at the operative level perceive a genuine need for changing established routines in order to fulfil their job, in this case to ensure the availability of well-qualified personnel for a functioning administration. These general rationalities might be even more relevant for changes if staff of immigrant origin is absent from managing positions, where they could advance diversity policies and practices as previous studies suggest (Cook and Glass 2015).

Investigating the case of local administrations in a German city-state, this study looked at a specific political and administrative context in a federal system. The organizational factors highlighted here are likely also relevant in other municipal administrations. At the same time, in the investigated case, the role of some environmental factors could not be further explored. Normative expectations in the organizational field, for instance, also shape organizational 
structures and practices (e.g. Dobbin, Kim, and Kalev 2011). Further, institutional factors such as the directive powers of the superior state levels and the binding character of diversity policies are likely to matter which differ from country to country. Moreover, the study focussed on a particular period of time - the introduction of policies and first measures. While this guaranteed comparability across administrations, the analysis of long-term effects of these policies on recruitment practices, and the workforce more generally, is beyond the scope of the study. Further research could extend our knowledge by focussing on different local and national contexts and by investigating the interplay of external institutional and internal organizational factors. Additionally, more research is desirable on the long-term impact of workforce diversity policies at different hierarchy levels including managing positions.

\section{Notes}

1. "Migration background" (Migrationshintergrund) is the official statistical category: "A person has a migration background if he or she or at least one parent does not have German nationality by birth" (Statistisches Bundesamt 2018, 4).

2. I understand workforce diversity policies as interventions promoting the inclusion of underrepresented social categories in the workforce. In this article, the term relates to migration-related diversity and to policies aiming to foster employment of staff of immigrant origin.

3. The structures are conceived as dynamic, constantly reproduced or modified by the organizational operations.

4. The conceptualization of persons as organizational structures is based on the premise that communication and not action is the basic unit of organizations and social systems in general (Nassehi 2005, 181-182). Persons are a structuring element of communication as authors, addressees and topics of communication.

5. The German sample census estimates a share of $6.7 \%$ for public administrations in 2013 (Ette et al. 2016, 32). More detailed data on administrative levels and units is not available.

6. Translation of the interview quotes by the author.

\section{Acknowledgements}

I would like to thank Karen Schönwälder, the other contributors of the Special Issue "Diversity in local political practice" as well as the anonymous reviewers for their helpful comments on earlier versions of this paper.

\section{Disclosure statement}

No potential conflict of interest was reported by the author(s).

\section{ORCID}




\section{References}

Abgeordnetenhaus von Berlin. 2010. Gesetz zur Regelung von Partizipation und Integration in Berlin. Berlin: Abgeordnetenhaus von Berlin.

Alexander, Michael. 2007. Cities and Labour Immigration. Comparing Policy Responses in Amsterdam, Paris, Rome and Tel Aviv. London: Ashgate.

Autorengruppe Bildungsberichterstattung. 2014. Bildung in Deutschland 2014. Ein indikatorengestützter Bericht mit einer Analyse zur Bildung von Menschen mit Behinderungen. Bielefeld: W. Bertelsmann Verlag.

Boswell, Christina. 2018. Manufacturing Political Trust. Targets and Performance Management in Public Policy. Cambridge: Cambridge Univ. Press.

Boxenbaum, Eva, and Stefan Jonsson. 2008. "Isomorphism, Diffusion and Decoupling." In The SAGE Handbook of Organizational Institutionalism, edited by Royston Greenwood, Christine Oliver, Roy Suddaby, and Kerstin Sahlin, 78-98. London: SAGE.

BQN Berlin. 2014. "Entwicklung des Anteils neuer Auszubildender mit Migrationshintergrund im Öffentlichen Dienst Berlins 2006-2013. Berlin: BQN.

Bromley, Patricia, and Walter W. Powell. 2012. "From Smoke and Mirrors to Walking the Talk: Decoupling in the Contemporary World." The Academy of Management Annals 6 (1): 483-530.

Brunsson, Nils. 2006. The Organization of Hypocrisy: Talk, Decisions and Actions in Organizations. 2nd ed. Copenhagen: Business School Press.

Bührmann, Andrea D., and Karen Schönwälder. 2017. "Public Organisations and Diversity: Approaches to an Under-Researched Topic." Journal of Ethnic and Migration Studies 43 (10): 1635-1643.

Cook, Alison, and Christy Glass. 2015. "The Power of One or Power in Numbers? Analyzing the Effect of Minority Leaders on Diversity Policy and Practice." Work and Occupations 42 (2): 183-215.

Creegan, Chris, Fiona Colgan, Richard Charlesworth, and Gil Robinson. 2003. "Race Equality Policies at Work: Employee Perceptions of the 'Implementation Gap' in a UK Local Authority." Work, Employment and Society 17 (4): 617-640.

Deephouse, David L., and Mark Suchman. 2008. "Legitimacy in Organizational Institutionalism." In The SAGE Handbook of Organizational Institutionalism, edited by Royston Greenwood, Christine Oliver, Roy Suddaby, and Kerstin Sahlin, 49-77. London: SAGE.

Dekker, Rianne, Henrik Emilsson, Bernhard Krieger, and Peter Scholten. 2015. "A Local Dimension of Integration Policies? A Comparative Study of Berlin, Malmö, and Rotterdam." International Migration Review 3 (49): 1-26.

Der Beauftragte des Senats von Berlin für Integration und Migration. 2005. Vielfalt fördern - Zusammenhalt stärken. Das Integrationskonzept für Berlin. Berlin: Der Beauftragte des Senats für Integration und Migration.

Der Beauftragte des Senats von Berlin für Integration und Migration. 2007. Vielfalt Fördern - Zusammenhalt stärken. Das Berliner Integrationskonzept. Berlin: Der Beauftragte des Senats für Integration und Migration.

Die Bundesregierung. 2012. Nationaler Aktionsplan Integration. Zusammenhalt stärken Teilhabe verwirklichen. Berlin: Presse- und Informationsamt der Bundesregierung.

Dobbin, Frank, Soohan Kim, and Alexandra Kalev. 2011. "You Can't Always Get What You Need: Organizational Determinants of Diversity Programs." American Sociological Review 76 (3): 386-411.

Edelman, Lauren B. 1992. "Legal Ambiguity and Symbolic Structures: Organizational Mediation of Civil Rights Law." American Journal of Sociology 97 (6): 1531-1576. 
Ette, Andreas, Susanne Stedtfeld, Harun Sulak, and Gunter Brückner. 2016. Erhebung des Anteils von Beschäftigten mit Migrationshintergrund in der Bundesverwaltung: Ergebnisbericht im Auftrag des Ressortarbeitskreises der Bundesregierung. Wiesbaden: Bundesinstitut für Bevölkerungsforschung.

George, Alexander L., and Andrew Bennett. 2005. Case Studies and Theory Development in the Social Sciences. Cambridge, MA: The MIT Press.

Gesemann, Frank, and Roland Roth. 2009. "Kommunale Integrationspolitik in Deutschland - Einleitende Bemerkungen." In Lokale Integrationspolitik in der Einwanderungsgesellschaft: Migration und Integration als Herausforderung von Kommunen, edited by Frank Gesemann and Roland Roth, 11-29. Wiesbaden: VS Verlag.

Gesemann, Frank, Roland Roth, and Jutta Aumüller. 2012. Stand der Kommunalen Integrationspolitik in Deutschland. Studie erstellt für das Bundesministerium für Verkehr, Bau und Stadtentwicklung und die Beauftragte der Bundesregierung für Migration, Flüchtlinge und Integration. Berlin: Bundesministerium für Verkehr, Bau und Stadtentwicklung.

Groeneveld, Sandra, and Stijn Verbeek. 2012. "Diversity Policies in Public and Private Sector Organizations: An Empirical Comparison of Incidence and Effectiveness." Review of Public Personnel Administration 32 (4): 353-381.

Hood, Christopher. 2006. "Gaming in Targetworld: The Targets Approach to Managing British Public Services." Public Administration Review 66 (4): 515-521.

Kalev, Alexandra, Frank Dobbin, and Erin Kelly. 2006. "Best Practices or Best Guesses? Assessing the Efficacy of Corporate Affirmative Action and Diversity Policies." American Sociological Review 71 (4): 589-617.

Kühl, Stefan. 2013. Organizations: A Systems Approach. Surrey: Gower.

Lang, Christine. 2019. Die Produktion von Diversität in Städtischen Verwaltungen. Wandel und Beharrung von Organisationen in der Migrationsgesellschaft. Wiesbaden: Springer.

Liff, Sonia, and Karen Dale. 1994. "Formal Opportunity, Informal Barriers: Black Women Managers Within a Local Authority." Work, Employment and Society 8 (2): 177-198.

Luhmann, Niklas. 1964. Funktionen und Folgen formaler Organisation. Berlin: Duncker \& Humblot.

Luhmann, Niklas. 2000. Organisation und Entscheidung. Opladen: Westdt. Verl.

Luhmann, Niklas. 2003. "Organization." In Autopoietic Organization Theory: Drawing on Niklas Luhmanns Social Systems Perspective, edited by Tore Bakken and Tor Hernes, 31-52. Oslo: Abstrakt, Liber.

Martínez-Ariño, Julia, Michalis Moutselos, Karen Schönwälder, Christian Jacobs, Maria Schiller, and Alexandre Tandé. 2019. "Why Do Some Cities Adopt More Diversity Policies Than Others? A Study in France and Germany." Comparative European Politics 17 (5): 651-672.

Meyer, John W., and Brian Rowan. 1977. "Institutionalized Organizations: Formal Structure as Myth and Ceremony." American Journal of Sociology 83 (2): 340-363.

Meziani-Remichi, Yamina, and Marcel Maussen. 2017. "Recruitment in Public Administrations: Diversity Policies and Selection Practices in a French City." Journal of Ethnic and Migration Studies 43 (10): 1679-1695.

Mosher, Frederick C. 1982. Democracy and the Public Service. 2nd ed. New York: Oxford Univ. Press.

Naff, Katherine C., and J. Edward Kellough. 2003. "Ensuring Employment Equity: Are Federal Diversity Programs Making a Difference?" International Journal of Public Administration 26 (12): 1307-1336. 
Nassehi, Armin. 2005. “Organizations as Decision Machines: Niklas Luhmann's Theory of Organized Social Systems." The Sociological Review 53 (1): 178-191.

Pitts, David W., Alisa K. Hicklin, Daniel P. Hawes, and Erin Melton. 2010. "What Drives the Implementation of Diversity Management Programs? Evidence From Public Organizations." Journal of Public Administration Research and Theory 20 (4): 867-886.

Schönwälder, Karen, and Triadafilos Triadafilopoulos. 2016. "The New Differentialism: Responses to Immigrant Diversity in Germany." German Politics 25 (3): 366-380.

Scott, W. Richard, and W. Meyer John. 1991. "The Organization of Societal Sectors: Propositions and Early Evidence." In The New Institutionalism in Organizational Analysis, edited by Walter W. Powell and Paul J. DiMaggio, 108-140. Chicago: Univ. of Chicago Press.

Seidl, David. 2003. "Organisational Identity in Luhmann's Theory of Social Systems." In Autopoietic Organization Theory. Drawing on Niklas Luhmann's Social Systems Perspective, edited by Tore Bakken and Tor Hernes, 123-150. Oslo: Abstrakt, Liber.

Solomos, John. 1989. “Equal Opportunities Policies and Racial Inequality: The Role of Public Policy." Public Administration 67 (1): 79-93.

Spencer, Sarah. 2008. Equality and Diversity in Jobs and Services: City Policies for Migrants in Europe. Dublin: European Foundation for the Improvement of Living and Working Conditions.

Statistisches Bundesamt. 2018. Bevölkerung und Erwerbstätigkeit: Bevölkerung mit Migrationshintergrund - Ergebnisse des Mikrozensus 2017. Wiesbaden: Statistisches Bundesamt. Accessed July 10 2019. https:/www.destatis.de/Migration/DE/ Publikationen/Thematisch/Bevoelkerung/MigrationIntegration/Migrationshintergrund. html.

Strauss, Anselm L., and Juliet Corbin. 1996. Grounded Theory: Grundlagen Qualitativer Sozialforschung. Weinheim: Beltz, Psychologie-Verlags-Union.

Young, Ken. 1987. "The Space Between Words: Local Authorities and the Concept of Equal Opportunities." In Racism and Equal Opportunity Policies in the 1980s, edited by Richard Jenkins and John Solomos, 93-109. Cambridge: Cambridge University Press. 